\title{
PEMIKIRAN PENDIDIKAN ISLAM MUHAMMAD ABDUH
}

\author{
Desri Arwen* E Kurniyati** \\ desriarwen@umt.ac.id,etykurniati@umt.ac.id \\ *Dosen Magister Pendidikan Agama Islam, Universitas Muhammadiyah Tangerang \\ **Dosen Magister Pendidikan Agama Islam, Universitas Muhammadiyah Tangerang
}

\begin{abstract}
The study aims to determine Muhammad Abduh's Islamic education thoughts. The effort made by Muhammad Abduh was to carry out reforms in the field of education which was motivated by the educational dichotomy at the time. First, Western education-based education whose curriculum is minus religious education. Second, religion-based education minus the general sciences. As a result of the integration of these two types of education, different human characters were born. The first character prefers worldly problems, and the second character only puts forward the problem of ukhrawi. The effort carried out by Muhammad Abduh was by reforming the goals of Islamic education which emphasized aspects of the world and the hereafter by carrying out an integral Islamic education curriculum (a combination of religious and general sciences), as well as effective, varied and innovative teaching methods.
\end{abstract}

Keywords: Muhammad Abduh, Education, Islam.

\section{A. PENDAHULUAN}

Lahirnya gagasan pembaruan pendidikan Islam $^{1}$ tak lepas dari para pengagasnya, salah satunya adalah Muhammad Abduh. Dia dikenal sebagai seorang pembaru pendidikan Islam yang

\footnotetext{
${ }^{1}$ Secara garis besar, ada beberapa faktor yang mendorong lahirnya pembaruan pendidikan Islam, yaitu: Pertama, faktor kebutuhan pragmatis umat Islam yang sangat memerlukan satu sistem pendidikan Islam yang betul-betul bisa dijadikan rujukan dalam rangka mencetak manusia-manusia muslim yang berkualitas. Kedua, agama Islam sendiri melalui ayat suci al Qur'an banyak menyuruh atau menganjurkan umat Islam untuk selalu berfikir dan bermetaforma: membaca dan menganalisisi sesuatu untuk kemudian bisa diterapkan atau bahkan bisa menciptakan hal yang baru dari apa yang dilihat. Ketiga, adanya kontak dengan Barat yang membawa perubahan paradigmatik umat Islam untuk belajar terus menerus kepada Barat, sehingga ketertinggalan-ketertinggalan yang selama ini dirasakan akan bisa terminimalisir. Lihat Suwito, Sejarah Sosial Pendidikan Islam, (Jakarta: Kencana, 2005), hal. 167
}

Tadarus Tarbawy. Vol. 1 No. 1 Jan - Jun 2019. pemikirannya memberikan kontribusi besar terhadap perubahan sistem pendidikan khususnya di Mesir dan umumnya di dunia pendidikan. Pengaruh pemikirannya dapat dirasakan dalam bidang reorganisasi pendidikan, tujuan pendidikan, dan metode pendidikan Islam ${ }^{2}$. Salah satu ide pembaruannya dalam pendidikan Islam adalah menghapus sistem pendidikan umat Islam yang terdikotomikan ${ }^{3}$ kepada sistem

\footnotetext{
${ }^{2}$ Sutrisno, Pendidikan Islam Yang Menghidupkan, (Yogyakarta: Penerbit Kota Kembang, 2008), hal. 20 ${ }^{3}$ Dikotomi adalah pemisahan suatu ilmu menjadi dua bagian yang satu sama lainnya saling memberikan arah dan makna yang berbeda dan tidak ada titik temu antara kedua jenis ilmu tersebut. Islam tidak menyepakati adanya dikotomi keilmuan, dan Islam menginformasikan kepada kita bahwa ilmu pengetahuan ada yang bersumber dari wahyu dan ada yang merupakan hasil berfikir ilmiah, yang kedua-duanya pada dasarnya bersumber dari Allah SWT. Samsul Nizar, Sejarah Pendidikan Islam: Menelusuri Jejak Sejarah Pendidikan Era Rasulullah Sampai Indonesia, (Jakarta: kencana, 2007), hal. 230-236
} 
tradisional (Islam) yang hanya mempelajari ilmu-ilmu agama dan modern (sekuler) yang mempelajari ilmu-ilmu pengetahuan umum. Menurutnya ilmu pengetahuan itu satu, yaitu berasal dari Allah SWT. Sebagian diwahyukan melalui ayat-ayat Qur'aniyah dan sebagian lain melalui ayat kauniyah $^{4}$. Bahkan al Qur'an mengajak ilmu pengetahuan tidak hanya terbatas pada ilmu agama dan syari'ah saja, namun al Qur'an juga mengajak mempelajari ilmuilmu alam dan ilmu-ilmu duniawi lainnya, karena ilmu-ilmu ini menjadi salah satu media atau sarana yang kuat untuk membangun dan meningkatkan standar kehidupan sosial, politik, ekonomi, budaya, dan militer. Dan jika direnungkan ayat-ayat al Qur'an dimanapun, akan didapati banyak nash-nash yang mendorong akal fikiran yang menuntut kepada penganalisaan dan diskusi serta berfikir dan pertimbangan yang jauh, untuk mencapai hakikat yang pasti. Sebagaimana firman Allah:

Katakanlah: "Berjalanlah di (muka) bumi, Maka perhatikanlah bagaimana Allah menciptakan (manusia) dari permulaannya, kemudian Allah menjadikannya sekali lagi. Sesungguhnya Allah Maha Kuasa atas segala sesuatu.(QS. Al Ankabut: 20)

Dengan membawa pemikirannya yang berisi tentang sistem pendidikan baru, ia berusaha mendobrak tembok sistem pendidikan agama tradisional dan pendidikan produk Barat yang telah dibangun sejak Muhammad Ali Pasya ${ }^{5}$ berkuasa.

Perjuangannya dalam upaya pembaruan pendidikan telah memberikan nilai-nilai yang berharga pada dunia pendidikan Islam yang meliputi pembaruan tujuan pendidikan Islam, materi pendidikan Islam, dan metode pendidikan Islam dari sistem tradisional menuju sistem modern.

\footnotetext{
${ }^{4}$ Muhaimin, Kontroversi Pemikiran Fazlur Rahman, Studi Kritis Pembaharuan Pendidikan Islam, (Cirebon: Pustaka Dinamika, 1999), hal. 110

${ }^{55}$ Pelopor pembaruan dan bapak pembangunan Mesir modern. Kebijakan dan gebrakannya lebih banyak mengadopsi tata cara dan model yang dilakukan Barat. Hafidz Dasoeki, Ensiklopedi Islam, (Jakarta: PT Ichtiar Baru Van Hoeve, 1995), hal.117
}

\section{B. PEMBAHASAN}

Muhammad Abduh lahir pada tahun 1849 di Mesir Hilir, kemudian menetap di Desa Marhalat, Mesir6. Muhammad Abduh lahir dan tumbuh menjadi dewasa dibawah asuhan ibu dan bapaknya yang taat beragama. Pendidikannya dimulai dengan belajar menulis serta menghafal al Qur'an. Kemudian pada tahun 1863 dia dikirim orangtuanya ke Thanta untuk mempelajari nahwu dan figh di masjid al Ahmadi. Ketika menuntut ilmu di Thanta, Muhammad Abduh merasa tidak puas dengan metode pengajarannya yang dinilai monoton, misalnya guru ketika mengajar hanya menyuruh menghafal yang artiartinya tidak difahami oleh murid-murid. Hal tersebut membuat Muhammad Abduh kecewa dan memutuskan untuk berhenti dalam menuntut ilmu.

Setelah lama vakum dalam menuntut ilmu, berkat dorongan semangat yang diberikan pamannya yang bernama Syekh Darwisy, maka Muhammad Abduh pun kembali ke Thanta untuk meneruskan pendidikannya. Setelah selesai menuntut ilmu di Thanta, kemudian Muhammad Abduh meneruskan studinya di al Azhar pada tahun $1866^{7}$. Di al Azhar ia bertemu dengan Jamaluddin al Afgani, dan belajar ilmu filsafat kepadannya. Selain berguru, ia pun sering berdiskusi perihal pembaruan yang kelak membawanya ke dalam dunia politik. Antara tahun 1882 dan $1888^{8}$ Muhammad Abduh diusir dari Mesir karena dianggap ikut serta dalam upaya menentang kekuasaan Khedewi Tawfik. Selama pengasingannya, ia tinggal di Paris dan Beirut. Selama pengasingan ia masih bersemangat melancarkan kegiatan politik dan dakwah yang bukan hanya ditunjukan kepada rakyat Mesir saja, akan tetapi kepada penganut Islam diseluruh dunia.

\footnotetext{
${ }^{6}$ Rif'at Syauqi Nawawi, Rasionalitas Tafsir Muhammad Abduh Kajian Masalah Ibadah, (Jakarta: Paramadina, 2002), hal. 22

${ }^{7}$ Harun Nasution, Pembaharuan Dalam Islam, (Jakarta: Bulan Bintang, 1996), hal 61

${ }^{8}$ John L. Esposito, Ensiklopedi Oxford Dunia Islam Modern, (Bandung: Mizan, 2002), hal 12.
} 
Bersama Jamaluddin al Afgani, ia menerbitkan majalah al Urwah al Wutsqa yang berisi tentang semangat pembaruan dalam dunia Islam dan membangkitkan umat Islam untuk melawan kekuasaan Barat. Disamping itu ia menulis sebuah buku yang sangat monumental yakni Risalah at Tauhid.

Pada tahun 1888 ia kembali ke Mesir setelah masa pengasingannya berakhir. Akan tetapi keinginannya untuk mengajar kembali ditolak oleh sang penguasa kala itu. Sebaliknya penguasa kala itu menawarkan kepada Muhammad Abduh untuk menjadi hakim di luar Kota Kairo. Akhirnya jabatan tersebut diterimanya dan dimanfaatkan untuk merealisasikan cita-cita pembaruannya $^{9}$

Lahirnya pembaruan pemikiran Muhammad Abduh dalam bidang pendidikan dilatarbelakangi dengan adanya dualisme pendidikan. Pertama, sekolahsekolah yang berorintasi pada pendidikan barat yang kurikulumnya hanya memuat ilmu pengetahuan dari Barat dan siswa tidak diajarkan sama sekali pendidikan agama. Kedua, sekolah-sekolah agama yang berorientasi hanya pada ilmu-ilmu agama tanpa ilmu pengetahuan yang lain. Munculnya dualisme tersebut berimplikasi kepada terbentuknya kepribadian yang tidak seimbang. Lulusan sekolah-sekolah yang berbasis pendidikan Barat melahirkan lulusan yang berwawaskan ilmu pengetahuan dan teknologi, tapi rendah dalam ilmu agama. Sedangkan lulusan sekolah-sekolah agama melahirkan para ulama yang miskin dalam wawasan intelektual serta enggan menerima perubahan atau perkembangan dan cenderung mempertahankan tradisi. Muhamamad Abduh melihat terdapat segisegi negatif dari kedua model pendidikan tersebut. Oleh karena itu ia memandang bahwa jika pola pendidikan yang pertama masih tetap dipertahankan, maka akan mengancam sendi-sendi ajaran Islam, karena pendidikan produk Barat yang

\footnotetext{
${ }^{9}$ Mahasri Shobahiya, Studi Kemuhammadiyahan: Kajian Historis, Ideologis, dan Organisatoris, (Surakarta: LPID UMS), hal. 15
}

diterapkan tanpa nilai-nilai religius akan berakibat degradasi moral. Dan jika pola pendidikan yang kedua masih tetap dipertahankan, maka akan mengakibatkan umat Islam tertinggal jauh dan semakin terdesak oleh arus kehidupan dan pola hidup modern.

Untuk mengatasi permasalah diatas, maka Muhammad Abduh melakukan pembaruan sistem pendidikan Islam dengan menggunakan langkah-langkah sebagai berikut:

\section{Reformasi tujuan pendidikan Islam}

Mundurnya pendidikan umat Islam kala itu dilatarbelakangi dengan tujuan pendidikan yang menurut Muhammad Abduh harus diperbarui. Lembaga-lembaga pendidikan yang berbasis pendidikan Barat yang didirikan pemerintah hanya bertujuan mengedepankan aspek kognitif yang mengejar duniawi saja. Sedangkan sekolah-sekolah agama yang didirikan kala itu hanya mengedepankan aspek spiritual yang terfokus pada masalah akhirat. Untuk itu Muhammad Abduh berusaha mereformasi kedua tujuan pendidikan tersebut ke arah yang dinamis. Menurut Muhammad Abduh tujuan pendidikan Islam adalah mendidik akal ${ }^{10}$ dan jiwa serta menyampaikannya kepada batas-batas kemungkinan seseorang dapat mencapai kebahagiaan hidup di dunia dan di akhirat ${ }^{11}$. Dari rumusan tujuan

\footnotetext{
${ }^{10} \mathrm{Al}$ Qur'an mengajak kepada pendidikan akal dan mengembangkannya dengan menggunakan media pendidikan yang beraneka ragam yang dapat meningkatkan cara berfikir yang benar dan matang. Sebaliknya, al Qur'an mengutuk orang-orang yang tidak mau menggunakan akal fikiran mereka, dan Allah mempersamakan mereka dengan binatang yang pekak tuli, sebagaimana firman Allah dalam QS. Al Anfal:22 “sesungguhnya binatang (makhluk) yang seburuk-buruknya di sisi Allah adalah orangorang yang pekak dan tuli yang tidak mengerti apaapa". Lihat Ali al Jumbulati, Perbandingan Pendidikan Islam, (Jakarta: Rineka Cipta, 2002), hal. 47

${ }^{11}$ Harun Nasution, Muhammad Abduh dan Teologi Rasional Mu'tazilah, (Jakarta: UI, 1987), hal. 190
} 
pendidikan tersebut, dapat dipahami bahwa yang ingin dicapai oleh Muhammad Abduh adalah tujuan yang mencakup aspek akal (kognitif) dan aspek spiritual (afektif). Ia menginginkan terbentuknya pribadi yang memiliki struktur jiwa yang seimbang antara aspek akal dan spiritual. Sehingga lahirlah manusia yang mampu berfikir serta memiliki akhlak yang mulia dan jiwa yang bersih. Pendidikan akal ditujukan sebagai alat untuk menanamkan kebiasaan berfikir dan tidak taklid ${ }^{12}$. Dengan menanamkan kebiasan berfikir, Muhammad Abduh berharap kebekuan intelektual yang melanda kaum muslim kala itu dapat dicairkan. Dan dengan pendidikan spiritual, diharapkan akan dapat melahirkan generasi baru yang tidak hanya mampu berfikir kritis, tetapi juga memiliki akhlak mulia serta jiwa yang bersih. ${ }^{13}$

Dalam kitabnya Risalah at Tauhid, Muhammad Abduh menyelaraskan antara akal dan agama. Ia berpandangan bahwa al Qur'an yang diturunkan dengan perantaraan lisan Nabi yang diutus Allah, telah mempertemukan akal dan agama. Oleh karena itu sudah merupakan ketetapan dikalangan kaum muslimin bahwa sebahagiaan dari ketentuan-ketentuan agama itu tidak dapat untuk meyakininya kecuali melalui akal. Dengan adanya ketentuan melalui hukum akal, dan terdapatnya ayat-ayat mutasyabihat di dalam al Qur'an, maka hal tersebut merupakan peluang besar bagi mereka yang suka berfikir terutama karena panggllan agama untuk senantiasa memikirkan semua makhluk Tuhan, dan tidak terbatas oleh

\footnotetext{
${ }^{12}$ Islam mengajak kepada penggunaan akal fikiran dan mendorong untuk mencari ilmu serta menganalisis hal-hal yang berada dibalik kenyataan alam ini. Lihat Fadhil al Djamali, Menerabas Krisis Pendidikan Dunia Islam, (Jakarta: Golden Terayon Press, 1988), hal. 15

${ }^{13}$ Suwito dan Fauzan, Sejarah Pemikiran Para Tokoh Pendidikan, (Bandung: Penerbit Angkasa, 2003), hal. 309
}

suatu pembatasan, dengan berkeyakinan bahwa segala pemikiran yang benar tentang ciptaan Tuhan akan membawa bertambahnya keimanan kepada Allah SWT ${ }^{14}$. Dengan demikian jika kedua aspek tersebut dididik dan dikembangkan, dalam arti akal dicerdaskan dan jiwa dididik dengan akhlak agama, maka umat Islam akan dapat terus maju serta mengimbangi bangsa-bangsa yang telah maju peradabannya.

\section{Reformasi Kurikulum Pendidikan Islam}

Tujuan pendidikan Islam yang telah dirumuskan Muhammad Abduh kemudian diaplikasikan dalam kurikulum dengan tingkatan pendidikan yang berbeda. Diantaranya kurikulum di Sekolah Dasar, Sekolah Menengah dan Kejuruan, serta Universitas al Azhar ${ }^{15}$.

a. Pengembangan kurikulum Sekolah Dasar

Menurut Muhammad Abduh bahwa dalam kurikulum sekolah dasar hendaknya dimasukan pelajaran agama disetiap kelas. Karena untuk membentuk jiwa agama hendaknya dilakukan pada masa kanak-kanak. Dengan demikian maka lahirlah pribadi muslim yang memilki jiwa kebersamaan dan nasionalisme yang selanjutnya dapat menjadi dasar bagi pengembangan sikap hidup yang lebih baik, dan sekaligus dapat meraih kemajuan ${ }^{16}$.

b. Pengembangan kurikulum Sekolah Menengah dan Kejuruan

Pengembangan kurikulum Sekolah Menengah dan Kejuruan dilakukan dengan memasukan mata pelajaran

\footnotetext{
${ }^{14}$ Muhammad Rasyid Ridha, Tarikh Ustadz al Imam al Syaikh Muhammad Abduh, (Mesir: Dar al Iman, 1367), hal. 511

${ }^{15}$ Abuddin Nata, Pemikiran Pendidikan Islam dan Barat, (Jakarta: Raja Grafindo Persada, 2012), hal 310

16 Abdul Sani, Lintasan Sejarah Pemikiran Perkembangan Modern dalam Islam, (Jakarta: Raja Grafindo Persada, 1998), hal. 53
} 
mantiq dan filsafat yang sebelumnya tidak boleh diajarkan. Selain itu dimasukan pula pelajaran sejarah peradaban Islam dengan tujuan agar umat Islam mengetahui berbagai kemajuan dan keunggulan yang pernah diraih umat Islam $^{17}$. Juga diberikan pelajaran syari'at, kemiliteran, ilmu pemerintahan tergantung dengan tujuan dan profesi yang pelajar inginkan ${ }^{18}$.

c. Pengembangan kurikulum di Universitas al Azhar

Universitas al Azhar sebelum diadakannya pembaruan kurikulum, mata kuliahnya hanya sebatas ilmuilmu agama saja ${ }^{19}$. Kemudian secara perlahan Muhammad Abduh melakukan pembaruan kurikulum, dengan cara memasukan ilmu filsafat, sosiologi, sejarah, dan lainlain. Kemudian dibentuk Dewan Admistrasi al Azhar (Idarah al Azhar) yang mengurusi masalah administrasi pendidikan dan Rauq al Azhar yang berfungsi sebagai asrama bagi dosen dan mahasiswa ${ }^{20}$.

\section{Reformasi Metode Pengajaran}

Dalam aspek metode pengajaran, Muhammad Abduh berusaha membawa cara baru dalam dunia pendidikan saat itu. Ia mengkritik tajam penerapan metode hafalan tanpa pengertian yang umumnya dipraktekkan disekolahsekolah agama. Menurutnya metode menghafal tanpa pengertian akan

\footnotetext{
${ }^{17}$ Abudin Nata, Pemikiran Pendidikan Islam dan Barat, hal. 311

${ }^{18}$ Margareth Marcus, Islam dan Modernisme, Terj. Jainuri dan Syafi'i A. Mughni, (Surabaya: Usaha Nasional, 1982), hal.80

${ }^{19}$ Karena kondisi al Azhar kala itu menganggap bahwa segala sesuatu yang berlawanan dengan kebiasaan merupakan sesuatu kekafiran. Membaca buku geografi, ilmu alam, dan filsafat adalah haram, bahkan dikatakan bid'ah. Quraish Shihab, Studi Kritis Tafsir al Manar, (Bandung: Pustaka Hidayah, 1994) hal. 13

${ }^{20}$ Abuddin Nata, Sejarah Pendidikan Islam Pada Periode Klasik dan Pertengahan, (Jakarta: Raja Grafindo Persada, 2004), hal. 192
}

merusak daya nalar, seperti yang pernah dialaminya ketika sekolah di Thanta. Menurutnya metode pengajaran yang selama ini hanya mengandalkan hafalan perlu dilengkapi dengan metode yang rasional dan pemahaman (insight). Dengan demikian, maka siswa nantinya bukan hanya saja hafal materi, akan tetapi juga memahami materi yang dihafal tersebut secara kompherensif.

Upaya pembaruan yang dilakukan Muhammad Abduh dalam metode pengajaran adalah dengan memasukan metode munadzarah (diskusi) ${ }^{21}$ dalam proses pengajaran. Tujuan dimasukkannya metode munadzarah adalah untuk memberikan peluang kepada pelajar didalam bertanya perihal pelajaran-pelajaran yang sukar dimengerti serta menumbuhkan sikap ilmiah.

Muhammad Abduh juga membuat sebuah metode yang sistematis dalam menafsirkan al

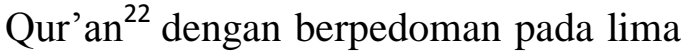
prinsip, yaitu: Pertama, menyesuaikan berbagai peristiwa yang ada dalam masyarakat dengan nash-nash al Qur'an. Kedua, menjadikan al Qur'an sebagai sebuah kesatuan. Ketiga, menjadikan surat sebagai dasar untuk memahami ayat. Keempat, menyederhanakan bahasa penafsiran. Kelima, tidak mengabaikan berbagai

\footnotetext{
${ }^{21}$ Metode diskusi juga diperhatikan oleh al Qur'an dalam mendidik dan mengajar manusia dengan tujuan lebih memantapkan pengertian, dan sikap pengetahuan mereka terhadap sesuatu masalah. Perintah Allah dalam hal ini adalah agar kita mengajak ke jalan yang benar dengan hikmah dan mauidzah yang baik dan membantah mereka dengan berdiskusi dengan cara paling baik sebagaimana firman Allah dalam QS. An Nahl: 125 dan QS. Al Ankabut: 46. Nur Uhbiyati, Ilmu Pendidikan Islam, (Bandung: Pustaka Setia, 1997), hal. 118-119

${ }^{22}$ Muhammad Abduh mengkritik cara kajian bukubuku di al Azhar yang lebih terfokus kepada membahas tafsiran-tafsiran orang dari pada teks aslinya. Lihat Suwito dan Fauzan, Sejarah Pemikiran Para Tokoh Pendidikan, hal. 311
} 
peristiwa sejarah yang menyertai turunnya ayat-ayat al Qur'an ${ }^{23}$.

\section{Konsep Pendidikan Wanita.}

Menurut Muhammad Abduh, wanita harus mendapatkan pendidikan yang sama dengan laki-laki. Lelaki dan wanita mendapat hak yang sama dari Allah, sesuai dengan firmanNya dalam al Qur'an surat al Baqarah: 228, serta dalam al Qur'an surat al Ahzab: 35. Dalam pandangan Muhammad Abduh ayat tersebut mensejajarkan lelaki dan wanita dalam hal mendapatkan keampunan, dan apabila yang diberikan Allah atas perbuatan yang sama, baik yang bersifat keduniaan maupun agama. Dari sini Muhammad Abduh bertolak bahwa perempuan pun punya hak mendapatkan pendidikan yang sama dengan laki-laki. Menurutnya, wanita harus dilepaskan dari rantai kebodohan, maka dari itu wanita perlu diberikan pendidikan

Demikian reformasi yang dilakukan Muhammad Abduh dalam bidang pendidikan, walaupun perjuangannya tersebut mendapatkan tantangan dan perlawanan dari kalangan ulama-ulama al Azhar ketika itu yang masih memiliki pola fikir tradisional yang tidak dapat menerima perubahan, akan tetapi perjuangan Muhammad Abduh tidak pernah surut demi meningkatkan kualitas pendidikan.

Meskipun usaha pembaruan pendidikan yang dilakukan Muhammad Abduh belum secara keseluruhan dapat direalisasikan, akan tetapi tetap memberikan pengaruh terhadap perubahan sistem pendidikan khususnya di Mesir dan umumnya pada dunia pendidikan Islam.

\section{KESIMPULAN}

Berdasarkan pembahasan yang telah diuraikan di atas, penulis dapat

${ }^{23}$ Harun Nasution, Pembaharuan Dalam Islam: Sejarah Pemikiran dan Gerakan, (Jakarta: Bulan Bintang, 1975), hal. 65 menyimpulkan bahwa Muhammad Abduh adalah salah seorang pembaru pendidikan Islam. Pembaruan-pembaruan yang dilakukannya meliputi; Pertama, pembaruan pada tujuan pendidikan Islam dari statis menuju dinamis dengan menekankan pada keseimbangan antara dua aspek, yakni aspek kognitif dan afektif. Kedua, melakukan pembaruan kurikulum dengan model integrated curriculum dengan cara memasukan pelajaranpelajaran filsafat, mantiq, ilmu pengetahuan alam, ditambah dengan ilmu-ilmu agama. Hal tersebut merupakan proses equalisasi secara proposional pendidikan keagamaan dan umum disekolah-sekolah modern dan tradisional. Ketiga, memasukan metode munadzarah atau metode diskusi dalam proses pembelajaran. Keempat, melakukan perbaikan administrasi dengan menentukan honorarium yang layak bagi ulama-ulama al Azhar, serta mendirikan gedung administrasi dan melakukan pengangkatan pegawai-pegawai untuk membantu rektor. Kelima, pendidikan wajib diberikan bagi wanita.

\section{DAFTAR PUSTAKA}

Dasoeki, Hafidz. Ensiklopedi Islam, Jakarta: PT Ichtiar Baru Van Hoeve, 1997.

Djamali, Fadhil. Menerabas Krisis Pendidikan Dunia Islam, Jakarta: Golden Terayon Press, 1988.

Esposito, John L. Ensiklopedi Oxford Dunia Islam Modern, Bandung: Mizan, 2002.

al Jumbulati, Ali. Perbandingan Pendidikan Islam, Jakarta: Rineka Cipta, 2002

Marcus, Margareth. Islam dan Modernisme, Terj. Jainuri dan Syafi'i A. Mughni, Surabaya: Usaha Nasional, 1982.

Muhaimin, Kontroversi Pemikiran Fazlur Rahman, Studi Kritis Pembaharuan Pendidikan Islam, Cirebon: Pustaka Dinamika, 1999.

Nasution, Harun. Pembaharuan Dalam Islam: Sejarah Pemikiran dan

Tadarus Tarbawy. Vol. 1 No. 1 Jan-Jun 2019. 
Gerakan, Jakarta: Bulan Bintang, 1975. Muhammad Abduh dan

Teologi Rasional Mu'tazilah, Jakarta: UI, 1987. Islam, Jakarta: Bulan Bintang 1996.

Nata, Abuddin. Sejarah Pendidikan Islam Pada Periode Klasik dan Pertengahan, Jakarta: Raja Grafindo Persada, 2004.

Pemikiran Pendidikan

Islam dan Barat, Jakarta: Raja

Grafindo Persada, 2012.

Nawawi, Rif'at Sayuqi. Rasionalitas Tafsir Muhammad

Nizar, Samsul. Sejarah Pendidikan Islam: Menelusuri Jejak Sejarah Pendidikan Era Rasulullah Sampai Indonesia, Jakarta: kencana, 2007.

Ridha, Muhammad Rasyid. Tarikh Ustadz al Imam al Syaikh Muhammad Abduh, Mesir: Dar al Iman, 1367.
Sani, Abdul. Lintasan Sejarah Pemikiran Perkembangan Modern dalam Islam, Jakarta: Raja Grafindo Persada, 1998.

Shihab, Quraish. Studi Kritis Tafsir al Manar, Bandung: Pustaka Hidayah, 1994.

Shobahiya, Mahasri. $\quad$ Studi Kemuhammadiyahan: Kajian Historis, Ideologis, dan Organisatoris, Surakarta: LPID UMS.

Sutrisno, Pendidikan Islam Yang Menghidupkan, Yogyakarta: Penerbit Kota Kembang, 2008.

Suwito, Sejarah Sosial Pendidikan Islam, Jakarta: Kencana, 2005.

---------, Sejarah Pemikiran Para Tokoh Pendidikan, Bandung: Penerbit Angkasa, 2003.

Uhbiyati, Nur. Ilmu Pendidikan Islam, Bandung: Pustaka Setia, 1997. 